\title{
O DIREITO À EDUCAÇÃO DOMICILIAR E OS NOVOS DESAFIOS AO SUPREMO TRIBUNAL FEDERAL: RECURSO EXTRAORDINÁRIO 888.815/RS, LACUNA LEGISLATIVA E DIREITO COMPARADO ${ }^{1}$
}

\author{
THE RIGHT TO HOMESCHOOLING AND THE NEW CHALLENGES TO THE \\ SUPREME FEDERAL COURT: EXTRAORDINARY REMEDY 888.815/RS, \\ LEGISLATIVE GAP AND COMPARATIVE LAW
}

\section{Estefânia Maria de Queiroz Barboza² \\ Karla Kariny Knihs ${ }^{3}$}

\begin{abstract}
Resumo
O presente artigo pretende analisar a situação jurídica da educação domiciliar no Brasil (prática conhecida como homeschooling), tendo em vista que não há legislação específica sobre o tema, o que levou inúmeras famílias brasileiras ao Judiciário a fim de pleitear o direito de retirar os filhos da escola e educá-los em casa. $\mathrm{O}$ crescimento do número de famílias que opta por esse tipo de educação tem como causa principal - mas não única - o sucateamento do ensino, conforme será demonstrado por dados estatísticos (embora a queda reiterada de qualidade não seja novidade). Outras causas relatadas são o aumento da violência e questões religiosas e morais. Após o estudo da realidade atual da educação domiciliar brasileira sob o viés jurídico, o enfoque do trabalho se dará sobre o Recurso Extraordinário (RE) 888815, em que se reconheceu a repercussão geral. No aludido recurso, se discute se o ensino domiciliar pode ser proibido pelo Estado ou considerado meio lícito de cumprimento, pela família, do dever de prover educação, nos termos do artigo 205 da Constituição Federal. Para tanto, além da questão constitucional, será discutida a possibilidade da utilização do direito comparado a fim de solucionar o embate, com breve estudo da realidade jurídica americana, país que possui mais de dois milhões de famílias homeschoolers.
\end{abstract}

Palavras-chave: Educação domiciliar. Homeschooling. Situação jurídica. Supremo Tribunal Federal. Direito comparado.

1 Artigo submetido em 28/03/2017, pareceres de análise em 26/04/2017 e 26/05/2017, aprovação comunicada em 21/07/2017.

2 Professora Adjunta do Departamento de Direito Público da Universidade Federal do Paraná e do Mestrado em Direito do Centro Universitário Internacional - UNINTER. Menção Honrosa no Prêmio Capes de Tese de 2012. Doutora e Mestre em Direito pela PUCPR. Vice-Presidente da Associação Ítalo-brasileira de Professores de Direito Administrativo e de Direito Constitucional. Email: <estefaniaqueiroz@uol.com.br>.

3 Mestranda em Direito pelo Uninter - Centro Universitário Internacional. Professora no Centro Universitário Internacional - UNINTER. Professora de graduação e pós-graduação na Faculdade Educacional Araucária - FACEAR. E-mail: <akarla@gmail.com>. 


\begin{abstract}
This article aims to analyze the legal situation of homeschooling in Brazil, given that there is no specific law about that, which led many Brazilian families to the Judiciary for the end of the right to remove children From school and teaching in home. The growth in the number of families choosing this type of education has as its main cause - but not a single one - the success of education, which is demonstrated by statistical data. Other reported causes are increased of violence and religious and moral issues. After the study of the current reality of Brazilian education, the objective of the work is Extraordinary Appeal (RE) 888815, in which a general repercussion was recognized. In the mentioned appeal, it is discussed the teaching of the domicile can be prohibited by the State, or by means of a diploma of compliance, by a family, of an article of law or of an article of 205 of the Federal Constitution. To do so, in addition to the constitutional question, it will be discussed in order to share the problem of integrating, with the study of American legal reality, the country that has more than two million homeschoolers.
\end{abstract}

Keywords: Home education. Homeschool education. Legal situation. Federal Court of Justice.

Sumário: 1. Introdução. 2. Educação domiciliar: uma realidade brasileira. 3. Homeschooling e a possível utilização do direito comparado pelo STF no julgamento do Recurso Extraordinário 888.815/RS. 4. Conclusão. 5. Referências.

\title{
1 INTRODUÇÃO
}

A Constituição Federal garante o direito à educação em vários dispositivos, tais como nos artigos 205, 206, 208, 210, 214 e 229. A legislação infraconstitucional pátria, por sua vez, traz diversos diplomas que tratam acerca do dever do Estado e dos pais em prover a educação, destacando-se entre eles a Lei de Diretrizes e Bases da Educação - LDB, o Estatuto da Criança de do Adolescente - ECA, o Código Penal e o Código Civil. Os tribunais, ao interpretarem tais dispositivos, formaram jurisprudência no sentido de que a não matrícula escolar configuraria ilícito penal e civil, condenando os poucos pais brasileiros que ousaram retirar seus filhos da escola, educando-os em casa, ao pagamento de multas e a rematrícula dos filhos, sob a alegação de que estariam praticando o crime de abandono intelectual.

Até recentemente, raríssimas eram as famílias que preferiam educar seus filhos em casa, sem matriculá-los em escolas, e a questão pouco chegava ao Judiciário. Entretanto, tendo em vista principalmente a má-qualidade da educação brasileira, o aumento da violência, bem como, por razões morais, filosóficas, políticas e/ou religiosas, várias famílias passaram a engrossar a estatísticas do 
aumento da prática da educação domiciliar, pleiteando o direito de educar seus filhos em casa, utilizando-se do homeschooling ${ }^{4}$. Daí nasce a polêmica em torno dos conceitos de educação e de escolarização - vez que os diplomas legais citados garantem o direito à educação, e não, especificamente, à escola.

O estudo se justifica tendo em vista que a questão da constitucionalidade da prática da educação domiciliar já chegou ao STF, sendo que há uma lacuna legislativa acerca do assunto. Muito embora vários projetos de lei e até mesmo proposta de Emenda Constitucional já tenham sido apresentados com o fim de regulamentar e permitir a educação domiciliar, ainda não há lei permitindo ou proibindo expressamente a prática. De tal forma que caberá ao Supremo a decisão sobre a constitucionalidade do ensino domiciliar, no Recurso Extraordinário $888.815 / \mathrm{RS}^{5}$.

O presente artigo tem como objetivo geral estudar de que forma o STF poderia se valer do Direito Comparado para a resolução da questão em exame no aludido Recurso Extraordinário, tendo em vista que mais de 60 países no mundo adotam a prática do homeschooling, bem como, 4 países a proíbem expressamente. Para tanto, se demonstrará brevemente o atual quadro da educação brasileira tanto no que concerne ao ensino escolarizado quanto à educação domiciliar -, bem como, serão estudados os dispositivos legais pátrios que tratam da educação, a fim de se entender a situação jurídica do ensino domiciliar no Brasil.

Por fim, será discutida a possibilidade de que o Supremo se valha das experiências estrangeiras sobre a matéria, para além da Constituição, obviamente, a fim de pacificar a polêmica em torno do direito à educação domiciliar, bem como, a fim de trazer uma resposta efetiva à sociedade.

Para que se possa entender os possíveis motivos para o crescimento da prática da educação domiciliar, bem como, para contextualizar o leitor acerca do tratamento legal dado atualmente à questão, no capítulo 2, são apresentados dados

4 Para a presente pesquisa, "homeschooling" trata-se da prática de educar os filhos em âmbito domiciliar, sem matriculá-los em escolas públicas ou privadas. Dentre os motivos mais frequentes para a escolha da educação domiciliar são apontados o baixo nível de qualidade educacional oferecida, o alto índice de violência, questões religiosas e questões relativas a divergências ideológicas.

5 Vide STF. Recurso Extraordinário 888.815/RS. Inteiro teor disponível em: <http://www.stf.jus.br/portal/jurisprudenciaRepercussao/verAndamentoProcesso.asp?incidente $=47$ 74632\&numeroProcesso=888815\&classeProcesso=RE\&numeroTema=822>. Acesso em: 19 mar. 2017. 
acerca da qualidade da educação oferecida nas escolas brasileiras, bem como, serão estudados os diplomas legais que tratam do direito à educação, inclusive, com a discussão de projeto de lei e proposta de emenda à Constituição que propõem permitir a prática da educação familiar.

No capítulo terceiro se tratará especificamente do Recurso Extraordinário 888.815/RS, bem como, serão feitas algumas reflexões acerca da possibilidade de o STF se utilizar do Direito Comparado na decisão do caso. Embora o artigo não possa esgotar o assunto, pretende-se traçar um panorama da educação domiciliar no Brasil e os possíveis caminhos que poderão ser tomados para a resolução do problema pelo Judiciário.

\section{EDUCAÇÃO DOMICILIAR: UMA REALIDADE BRASILEIRA}

Segundo dados do Ministério de Educação ${ }^{6}$, o orçamento para custeio da educação cresceu 205,7\% em dez anos, ao passar de R\$ 33,3 bilhões em 2003 para $R \$ 101,86$ bilhões em 2013. Para o ano de 2017 , esse valor chegará a $R \$$ 138,97 bilhões. Em 20 anos, o Brasil passou do investimento de $4 \%$ ao de $6 \%$ do PIB em educação. Houve, portanto, um sensível aumento dos recursos para essa área. Entretanto, a média dos alunos nas avaliações do MEC não acompanha o crescimento orçamentário: no ano de 2015, 91\% das escolas públicas ficaram abaixo da média no ENEM ${ }^{7}$. Entre as escolas particulares, no mesmo ano, o percentual é de $17 \%$. Tais dados revelam uma falência do sistema educacional brasileiro. Lamentavelmente, o ENEM, que vinha servindo não só como forma de ingresso em universidades, mas também como forma de avaliação da qualidade das escolas brasileiras, não mais publicará o 'ranking', como era praxe. A partir deste ano de 2017, as escolas que oferecerem o terceiro ano do ensino médio passarão a ter o Índice de Desenvolvimento da Educação Básica (Ideb). Este será o único indicador de qualidade disponível, já que o as notas do Enem não serão mais divulgadas por escola ${ }^{8}$.

6 BRASIL. MEC. Disponível em: <http://portal.mec.gov.br/component/content/article?id=39021>. Acesso em: 04 jan. 2017.

7 Disponível em: <http://www1.folha.uol.com.br/educacao/2016/10/1819634-91-das-escolaspublicas-ficaram-abaixo-da-media-no-enem-2015.shtml>. Acesso em: 05 jan. 2017.

8 GLOBO. 'Ranking' do Enem por escolas deixará de existir; entenda a mudança. Disponível em: <http://g1.globo.com/educacao/enem/2017/noticia/ranking-do-enem-por-escolas-deixara-de-serdivulgado-diz-mec.ghtml>. Acesso em: 19 mar. 2017. 
O MEC é o principal responsável pelo sucateamento da educação no Brasil. Para se ter uma ideia do atual estado das coisas, dados de $2013^{9}$ dão conta de que $75 \%$ dos brasileiros entre 15 e 65 anos não conseguem ler e escrever de modo satisfatório. Uma pesquisa da Universidade Católica de Brasília aponta que mais de $50 \%$ dos universitários são analfabetos funcionais, ou seja, não conseguem sequer compreender o que leem ${ }^{10}$. Tais dados demonstram que a educação está comprometida desde o ensino fundamental até o ensino superior. Por fim, o Inaf ${ }^{11}$ (Indicador de Alfabetismo Funcional) aponta que somente $8 \%$ das pessoas em idade de trabalhar são consideradas plenamente capazes de entender e se expressar por meio de letras e números. De outro lado, dados do IBGE apontam que a Taxa de escolarização das pessoas de 6 a 14 anos de idade, por sexo, no Brasil entre 2007/2014 ultrapassa $98 \%{ }^{12}$. Como é possível que hajam tantos analfabetos funcionais, inclusive nas universidades, se a taxa de escolarização é tão elevada? $\mathrm{Na}$ área de educação, apenas $16 \%^{13}$ dos profissionais tem alto nível de alfabetização, e isso diz muito sobre a raiz do problema.

Quando se compara o desempenho dos estudantes brasileiros na esfera internacional, a gravidade é ainda maior. No ano de 2014 , o Brasil ficou em $38^{\circ}$ lugar no ranking mundial de educação, de 40 países avaliados em exame realizado pelo The Economist Intelligence Unit ${ }^{14}$, a frente apenas do México e da Indonésia. No PISA - Programa Internacional de Avaliação de Alunos, o Brasil ocupava a $40^{\mathrm{a}}$ posição no ranking de educação, no ano 2000 , passando para a posição $55^{a}$ no ano de 2012 (de 65 participantes) e em 60 em 2015 (de 73 participantes) ${ }^{15}$.

A queda do nível educacional brasileiro não é novidade e está em pauta há muito tempo, inclusive nos noticiários nacionais. Algumas famílias, diante do

9 INSTITUTO PAULO MONTENEGRO. Indicador de analfabetismo funcional. Disponível em: <http://www.ipm.org.br/pt-br/programas/inaf/Paginas/default.aspx>. Acesso em: 05 jan. 2017.

10 Reportagem disponível em: <http://g1.globo.com/distrito-federal/videos/v/pesquisador-conclui-quemais-de-50-dos-universitarios-sao-analfabetos-funcionais/2262537/>. Acesso em: 05 jan. 2017.

11 Vide informações disponíveis em: <https://educacao.uol.com.br/noticias/2016/02/29/no-brasilapenas-8-escapam-do-analfabetismo-funcional.htm>. Acesso em:10 jan. 2017.

12 Vide gráfico em: <http://brasilemsintese.ibge.gov.br/educacao/taxa-de-escolarizacao-das-pessoasde-6-a-14-anos.html>. Acesso em: 29 dez. 2016.

13 Informações disponíveis em: <http://www.revistaeducacao.com.br/apenas-16-dos-profissionais-daeducacao-pode-ser-considerado-completamente-alfabetizado-diz-estudo/>. Acesso em: 05 jan. 2017.

14 Dados disponíveis em: The Economist Intelligence Unit Limited <http://country.eiu.com/brazil>. Acesso em: 12 jan. 2017.

15 Dados disponíveis em: <http://www.oecd.org/pisa/>. Acesso em: 12 jan. 2017. 
evidente colapso da educação, procuram formas de garantir aos filhos maior qualidade de ensino. Há aquelas que sacrificam grande parte da renda matriculando-os em escolas particulares, ou pagando tutores para a realização do reforço escolar. Outras, preferem desafiar o sistema educacional dito obrigatório, retirando-os da escola e passando a realizar a educação em âmbito domiciliar, ou homeschooling, como é conhecida a prática da educação em casa. Há até quem mande o filho para a escola por receio de reprimendas legais, em meio período, mas pratique o homeschooling.

A prática da educação domiciliar tem crescido nos últimos anos, principalmente, em razão da queda da qualidade do ensino público e do aumento da violência escolar, embora haja também famílias que se apoiam em motivos morais e religiosos para a prática do homeschooling. A Associação Nacional de Educação Domiciliar $^{16}$ afirma que cerca de seis mil crianças brasileiras (em 3,2 mil famílias) são educadas em casa, sendo que o número pode ser ainda maior, tendo em vista que muitas famílias optam por não divulgar tal informação, por medo de serem denunciadas. Isso porque é comum que as famílias que não enviam seus filhos à escola recebam a visita do Conselho Tutelar, e, posteriormente, sejam denunciadas à justiça pelo Ministério Público, sob a alegação de que estão cometendo o crime de abandono intelectual dos filhos, nos termos do art. 246 do Código Penal ${ }^{17}$. Os pais podem responder não só criminalmente, mas também, na esfera cível, sendo multados.

Hoje, várias famílias estão respondendo perante a justiça em razão de adotarem a prática do homeschooling, tanto que a questão já chegou ao STF, como já dito. Entretanto, para imprimir a realidade brasileira ao presente estudo, trataremos brevemente de um dos casos pioneiros: o da família de Cleber e Bernadete Nunes ${ }^{18}$. No ano de 2010, o Juizado Especial Criminal da comarca de Timóteo (MG) condenou o casal ao pagamento de multa por abandono intelectual dos dois filhos adolescentes, retirados da escola no ano de 2005. Na esfera cível, a $1^{\text {a }}$ Vara Cível da Comarca de Timóteo condenou o casal a re-matricular os filhos em

16 Disponível em: <http://www.educacao-domiciliar.com/category/artigos/questoes-legais/>. Acesso em: 12 jan. 2017.

17 Abandono intelectual

Art. 246 - Deixar, sem justa causa, de prover à instrução primária de filho em idade escolar: Pena - detenção, de quinze dias a um mês, ou multa.

18 Vide <http://uj.novaprolink.com.br/doutrina/6508/O_Caso_Nunes_Homeschooling_Liberdade_e _llicito_Legal.>. Acesso em: 12 jan. 2017. 
escola e a pagar multa de 12 salários mínimos. O Recurso do casal foi indeferido por unanimidade pela $4^{a}$ Câmara Cível do Tribunal de Justiça de Minas Gerais (TJMG), sob a relatoria do Desembargador José Tarcizio de Almeida Melo ${ }^{19}$. (FERNANDEZ et. all, 2009)

Os pais, apesar de terem se aborrecido com os processos no início, resolveram simplesmente ignorar a justiça: não mais recorreram, não procederam a matrícula, jamais pagaram qualquer multa e, após todos esses anos, os filhos não pensam em cursar faculdade e já foram premiados em vários eventos científicos, demonstrando serem brilhantes inventores.

O caso em tela é emblemático, e não se presta apenas a demonstrar a inefetividade do Poder Judiciário, mas sim, serve para ilustrar o fato de que a situação jurídica da educação domiciliar é nebulosa: tanto é assim que todos os processos que versam sobre a matéria estão suspensos por decisão do Ministro Barroso, do Supremo Tribunal Federal ${ }^{20}$. Não há legislação específica sobre o tema: a prática não é expressamente proibida, mas também não é expressamente permitida.

Há, inclusive, vários projetos de lei versando sobre a regulação da prática da educação domiciliar. Dentre eles, damos destaque ao Projeto de Lei 3179/2012²1, que pretende acrescentar parágrafo ao art. 23 da Lei 9.394, de 1996, de Diretrizes e Bases da Educação Nacional, para dispor sobre a possibilidade de oferta domiciliar da educação básica. Assim, a LDB passaria a ter a seguinte redação:

$\S 3^{\circ}$ É facultado aos sistemas de ensino admitir a educação básica domiciliar, sob a responsabilidade dos pais ou tutores responsáveis pelos

19 Ementa: ESTATUTO DA CRIANÇA E DO ADOLESCENTE. PODER FAMILIAR. DEVER. DESCUMPRIMENTO. EDUCAÇÃO. EVASÃO ESCOLAR. INFRAÇÃO ADMINISTRATIVA. MULTA. O descumprimento do dever de ensinar os filhos, em rede regular, com a permissão á evasão da escola, caracteriza infração tipificada no art. 249 do Estatuto da Criança e do Adolescente, ensejando a aplicação da sanção pecuniária prevista naquele dispositivo contra os pais. Rejeita-se a preliminar e nega-se provimento à apelação. (Apelação Cível 1.0687.07.0542869/001. 0542869-16.2007.8.13.0687 (1). Rel. Des. Almeida Melo. Comarca de Origem: Timóteo. Data de Julgamento: 04/12/2008. Data da publicação da súmula: 22/01/2009. Divulgação: REVISTA JURISPRUDÊNCIA MINEIRA, v. 187/183. Disponível em: <http://www4.tjmg.jus.br/ juridico/sf/proc_resultado2.jsp?listaProcessos=10687070542869001>. Acesso em: 19 mar. 2017.

20 Vide STF. Recurso Extraordinário 888.815/RS. Inteiro teor disponível em: <http://www.stf.jus.br/portal/jurisprudenciaRepercussao/verAndamentoProcesso. asp?incidente $=47$ 74632\& numeroProcesso $=888815$ \&classeProcesso=RE\&numeroTema=822 $>$. Acesso em 19 mar. 2017.

21 Disponível em: <http://www.camara.gov.br/proposicoesWeb/fichadetramitacao?idProposicao=534328>. Acesso em: 12 jan.. 2017. 
estudantes, observadas a articulação, supervisão e avaliação periódica da aprendizagem pelos órgãos próprios desses sistemas, nos termos das diretrizes gerais estabelecidas pela União e das respectivas normas locais.

Na exposição dos motivos do Projeto ${ }^{22}$, o autor, Deputado Lincoln Portela, afirma que embora a Constituição Federal estabeleça que a educação seja dever do Estado e da família (art. 205) e que determine também a obrigatoriedade da educação básica, dos 4 aos 17 anos de idade (art. 208, I), não haveria impedimento para que a mesma formação, se assegurada a sua qualidade e o devido acompanhamento pelo Poder Público certificador, fosse oferecida no ambiente domiciliar, caso seja essa a opção da família do estudante. O projeto de lei em comento chegou a ter votação marcada na Comissão de Educação da Câmara, para o dia 14/12/2016. Entretanto, foi retirado de pauta após uma manobra regimental.

Há, também, sobre a matéria, proposta de Emenda à Constituição de autoria de Wilson Picler23. A PEC 444/09 pretende acrescentar um parágrafo ao artigo 208, nos seguintes termos: " $§ 4^{\circ}$ - O Poder Público regulamentará a educação domiciliar, assegurado o direito à aprendizagem das crianças e jovens na faixa etária da escolaridade obrigatória por meio de avaliações periódicas sob responsabilidade da autoridade educacional."

Afirma Wilson Picler ser necessário que o Estado regulamente o direito à educação domiciliar, de tal forma que os pais ou responsáveis possam obter da autoridade competente a autorização para educar seus filhos em casa e que as crianças e jovens sejam regularmente avaliados pela rede oficial de ensino. A PEC encontra-se arquivada desde o ano de 2015.

Citamos aqui os mais relevantes projetos, mas vários outros encontram-se arquivados $^{24}$. Então, novamente, por falta de iniciativa do legislativo, o problema continua nas mãos do assoberbado Supremo Tribunal Federal. Assim, apesar de não haver legislação específica sobre o assunto, a questão acerca do direito de educar as crianças e adolescentes em casa está sendo discutida no Recurso

22 O texto e o andamento atual podem ser consultados em: <http://www.camara.gov.br/ proposicoesWeb/fichadetramitacao?idProposicao=534328>. Acesso em: 05 jan. 2017.

23 BRASIL. Projeto de Emenda à Constituição $n^{\circ} 444$ de 2009. A PEC e sua justificativa podem ser consultadas em: <http://www.camara.gov.br/proposicoesWeb/ prop_mostrarintegra?codteor= 723417\&filename=Tramitacao-PEC+444/2009>. Acesso em: 17 jan. 2017.

24 Por exemplo: Projetos de Lei 3518/2008 e 4122/2008. Os motivos apontados pelos autores dos projetos para a sua apresentação destacam a má qualidade do ensino básico, a violência nas escolas e as questões de ordem religiosa. 
Extraordinário $888.815 / \mathrm{RS}^{25}$ que teve origem em mandado de segurança impetrado pelos pais de uma menina de 11 anos, em face da secretaria de Educação do Município de Canela, no Rio Grande do Sul. O ato atacado diz respeito à negativa do pedido dos pais para que a criança fosse educada em casa, sendo determinada a matrícula da mesma na escola em que já estava estudando no ano anterior. No caso, o juízo da Comarca de Canela e o Tribunal de Justiça do Estado do Rio Grande do Sul indeferiram o mandado de segurança, alegando não haver previsão legal de ensino domiciliar. Anteriormente, a família Vilhena Coelho, de Anápolis/GO, foi a primeira a discutir judicialmente a questão, de forma que o Superior Tribunal de Justiça teve oportunidade de decidir sobre a matéria em $2001^{26}$. Nota-se, portanto, que a discussão é relativamente recente, mas que tem tomando proporções cada vez maiores.

Antes de adentrarmos no mérito do Recurso Extraordinário e do desafio lançado ao STF, é necessário o estudo da legislação pátria, a fim de situar o leitor acerca do atual tratamento jurídico dado ao ensino domiciliar bem como, conhecer dos artigos constitucionais que são evocados no Recurso Extraordinário estudado.

Primeiramente, devem ser analisados os artigos 205 e 208 da Constituição Federal. O artigo 205 dispõe que "A educação, direito de todos e dever do Estado e da família, será promovida e incentivada com a colaboração da sociedade, visando ao pleno desenvolvimento da pessoa, seu preparo para o exercício da cidadania e sua qualificação para o trabalho".

O artigo 208, por sua vez, traz que "O dever do Estado com a educação será efetivado mediante a garantia de: I - educação básica obrigatória e gratuita dos 4 (quatro) aos 17 (dezessete) anos de idade, assegurada inclusive sua oferta gratuita para todos os que a ela não tiveram acesso na idade própria." Tais dispositivos devem ser aliados à redação do art. 229 da CF, segundo o qual "Os pais têm o dever de assistir, criar e educar os filhos menores".

Em um primeiro momento, pode parecer que a Constituição Federal torna obrigatória a matrícula das crianças em escola, a partir dos quatro até os dezessete

25 Vide STF. Recurso Extraordinário 888.815/RS. Inteiro teor disponível em: <http://www.stf.jus.br/ portal/jurisprudenciaRepercussao/verAndamentoProcesso. asp?incidente $=4774632 \&$ numeroProce Sso=888815\&classeProcesso=RE\&numeroTema=822>. Acesso em 19 mar. 2017.

26 STJ. MANDADO DE SEGURANÇA No 7.407 - DF (2001/0022843-7). Disponível em: <http://www.mp.go.gov.br/portalweb/hp/42/docs/ms-ensino_fundamental-7407_stj.pdf $>$. Acesso em: 19 mar. 2017. 
anos de idade. Entretanto, é necessário atentar ao fato que a obrigatoriedade não diz respeito à escolarização obrigatória, mas sim à educação obrigatória, sendo o conceito de educação bastante diferente e mais amplo que o de escolarização (AGUIAR, 2011).

Para Alexandre Magno Fernandes Moreira Aguiar (2011), “a educação, que começa com o nascimento do indivíduo, deve assumir uma feição formal quando ele tem de 4 a 17 anos", o que não significa, obrigatoriamente, que a educação só possa ser possível mediante a matrícula escolar (ou com a escolarização obrigatória).

Nas palavras do autor:

\begin{abstract}
Para alcançar essas finalidades, os pais podem, se tiverem as condições necessárias, educar os filhos em casa. Mais ainda: de qualquer forma, a educação deve ser realizada em casa. A própria CF reconhece isso ao dispor, no art. 229, que "os pais têm o dever de assistir, criar e educar os filhos menores". Portanto, a educação domiciliar não apenas é permitida, mas também exigida dos pais.
\end{abstract}

O artigo 206 da Constituição Federal elenca os princípios que devem ser observados no que se refere ao ensino, sendo importante destacar, entre eles: "II liberdade de aprender, ensinar, pesquisar e divulgar o pensamento, a arte e o saber;" "III - pluralismo de ideias e de concepções pedagógicas, e coexistência de instituições públicas e privadas de ensino;" "VII - garantia de padrão de qualidade."

Para os defensores da prática da educação familiar, a obrigatoriedade de matrícula escolar, especialmente se considerando a prova da falta de qualidade da educação brasileira oferecida nas escolas, fere o inciso II do art. 206, tolhendo o direito de aprender e ensinar.

Por fim, o artigo 229 da Constituição Federal dispõe que os pais têm o dever de assistir, criar e educar os filhos menores, e os filhos maiores têm o dever de ajudar e amparar os pais na velhice, carência ou enfermidade. Esse dispositivo é suscitado como primordial para o entendimento de que a escolarização não deva ser obrigatória - mas sim a educação - tendo em vista que o próprio Estado brasileiro não cumpre com o seu papel, oferecendo educação de baixa qualidade e formando um exército de analfabetos funcionais diplomados. 
Entretanto, a discussão permite argumentação além do âmbito constitucional. A legislação infraconstitucional também dá margem a interpretações divergentes. Primeiramente, se analisa a LDB - Lei de Diretrizes e Bases (Lei 9.394, de 20 de dezembro de 1996).

O artigo $4^{\circ}$ da referida lei dispõe: "O dever do Estado com educação escolar pública será efetivado mediante a garantia de: I - educação básica obrigatória e gratuita dos 4 (quatro) aos 17 (dezessete) anos de idade, organizada da seguinte forma". Novamente, o texto legal trata do dever de educação obrigatória, não de escolarização obrigatória.

Ainda, o artigo $6^{\circ}$ assim dispõe: "É dever dos pais ou responsáveis efetuar a matrícula das crianças na educação básica a partir dos 4 (quatro) anos de idade.”. O texto trata do dever de matrícula pelos pais, ou responsáveis, mas não trata da obrigatoriedade de matrícula, nem proíbe a não matrícula, vez que o que se pretende é a educação básica, e não a escolarização básica.

O ECA - Estatuto da Criança e do Adolescente, por sua vez, traz a seguinte disposição: "Art. 55. Os pais ou responsável têm a obrigação de matricular seus filhos ou pupilos na rede regular de ensino".

A primeira vista, a disposição do ECA parece não deixar dúvidas de que a escolarização - acima da educação - é obrigatória. Entretanto, a norma não deve ser interpretada isoladamente. Isso porque o próprio ECA afirma que na sua interpretação deverão ser levados em conta os fins sociais a que a lei se dirige, as exigências do bem comum, os direitos e deveres individuais e coletivos, e a condição peculiar da criança e do adolescente como pessoas em desenvolvimento (art. $6^{\circ}$ ). Ou seja: a doutrina da proteção integral protege o melhor interesse do menor e qualquer norma que venha de encontro a esse interesse deixa de ser obrigatória. De tal forma que a matrícula somente é obrigatória caso os pais ou responsáveis não possam ou não queiram prover a educação domiciliar (AGUIAR, 2011).

Por fim, temos a previsão do Código Penal, que no artigo 246 pune com detenção de 15 dias a um mês, ou multa, aquele que sem justa causa deixa de prover a instrução primária do filho em idade escolar.

Mais uma vez, parece que a lei é implacável quanto a obrigatoriedade da matrícula escolar. Entretanto, é interessante aliar esse dispositivo ao artigo 125 da 
$\mathrm{CF} / 37$, vigente à época da redação do dispositivo penal: "A educação integral da prole é o primeiro dever e o direito natural dos pais. O Estado não será estranho a esse dever, colaborando, de maneira principal ou subsidiária, para facilitar a sua execução ou suprir as deficiências e lacunas da educação particular.". Veja-se que a interpretação dos dispositivos dá azo ao entendimento de que o Estado é um auxiliar dos pais na educação, havendo abandono intelectual apenas se os pais não proverem essa educação, e não apenas pela mera falta da matrícula escolar.

Por fim, o Código Civil traz o art. 1.634, com a seguinte redação: "Compete aos pais, quanto à pessoa dos filhos menores: I - dirigir-lhes a criação e educação".

Com base nesses dispositivos legais, não resta dúvida de que cabe ao Estado e à família, de forma conjunta, prover a educação das crianças e adolescentes. Entretanto, a obrigatoriedade da escolarização é discutível. (AGUIAR, (2011).

Indo mais além, a educação brasileira oferecida é de tão baixa qualidade e os índices de violência escolar ${ }^{27}$ assustam tanto, que se pode afirmar existir um verdadeiro "estado de necessidade educacional" 28 . O estado de necessidade pode ser caracterizado tanto no âmbito civil, quanto no âmbito penal. O art. 188 do Código Civil preceitua que não constituem atos ilícitos "I - os praticados em legítima defesa ou no exercício regular de um direito reconhecido; II - a deterioração ou destruição da coisa alheia, ou a lesão a pessoa, a fim de remover perigo iminente." De tal forma que os pais podem defender o melhor interesse do menor quando entenderem que a escolarização é prejudicial ao filho, bem como, oferecendo melhores condições de educação no âmbito do lar, estejam agindo em legítima defesa, evitando lesão à personalidade da criança.

Ainda, em âmbito penal, também é possível aplicar o conceito de "estado de necessidade educacional". No Brasil, o estado de necessidade, previsto no artigo 23, inciso I, do Código Penal, é uma causa especial de exclusão de ilicitude. Segundo a redação do artigo, não há crime quando o agente pratica o fato em estado de necessidade. Como a educação domiciliar não é sinônimo de abandono intelectual, bem como se exercida em prol do melhor interesse da criança, tendo em vista os

27 BBC. Pesquisa põe Brasil em topo de ranking de violência contra professores. Disponível em: <http://www.bbc.com/portuguese/noticias/2014/08/140822_salasocial_eleicoes_ocde_valorizacao_ professores_brasil_daniela_rw>. Acesso em: 19 mar. 2017.

28 Conforme Aguiar (2011): "Estado de necessidade educacional: situação em que os pais retiram os filhos da escola em razão da péssima qualidade das opções disponíveis". 
relatados problemas de baixa qualidade da educação, violência, etc., o estado de necessidade educacional é uma causa que retira o caráter antijurídico de um fato tipificado como crime. Segundo o artigo 24 do Código Penal, considera-se em estado de necessidade quem pratica o fato para salvar de perigo atual, que não provocou por sua vontade, nem podia de outro modo evitar, direito próprio ou alheio, cujo sacrifício, nas circunstâncias, não era razoável exigir-se. Ilustrativamente, citase o caso da mãe que, aos prantos, vendo o filho incapaz de ler e escrever aos doze anos de idade, obrigou a criança a faltar cinquenta e um por cento das aulas para forçar a reprovação, proporcionando-lhe a chance de rever o conteúdo ${ }^{29}$. Ou o caso da mãe e estudante de pedagogia que implorou para que a escola reprovasse o filho de dez anos de idade, que não sabia ler e escrever ${ }^{30}$.

Por fim, deve-se atentar, também, para a questão de a quem competiria a prioridade de educação: aos pais ou ao Estado. A Declaração Universal dos Direitos Humanos dispõe, em seu artigo 26, $\S 3$ que "os pais têm prioridade de direito na escolha do gênero de instrução que será ministrada a seus filhos". O direito de escolha do gênero de educação é, portanto, Direito Humano Absoluto previsto em tratado ratificado pelo Brasil em 1948, não podendo ser derrogado pelos signatários nem em situações de grave emergência nacional ou de guerra.

Assim, não restam dúvidas que a escolha da educação dos filhos compete aos pais e que se esses, em prol do melhor interesse da criança, decidem que a melhor forma de provê-la é através da educação domiciliar, não haveria qualquer empecilho a sua adoção. E mais: proibir a prática implica em flagrante violação aos Direitos Humanos.

A verdade é que por questões práticas a grande maioria dos pais prefere matricular os filhos em escolas, e para isso o Estado deve cumprir seu papel de auxiliar da educação. Contudo, as famílias que optam pelo homeschooling vivem em um verdadeiro limbo, pois, embora não pretendam abandonar seus filhos intelectualmente, estão sob a ameaça de serem acionadas pelo Ministério Público, que infelizmente adota posicionamento de que a prática da educação domiciliar configura ilícito penal e civil.

29 GLOBO. Série "Lições da Escola". Reportagem disponível em: <Https://www.youtube.com/ watch?v=cSA239Vnrgq>. Acesso em: 19 mar. 2017.

30 GLOBO. Mãe pede para escola reprovar aluno de 10 anos que não sabe ler. Disponível em: <http://g1.globo.com/mato-grosso/noticia/2014/02/mae-implora-para-escola-reprovar-aluno-de-10anos-que-nao-sabe-ler.html>. Acesso em: 19 mar. 2017. 
A partir disso, inúmeras famílias aguardam uma reposta. O Supremo Tribunal Federal já reconheceu a repercussão geral no Recurso Extraordinário 888.815/RS, em que se discute a constitucionalidade do ensino domiciliar, e suspendeu a tramitação de todas as ações que tratem da matéria ${ }^{31}$.

No capítulo seguinte passaremos a analisar a questão da constitucionalidade da educação domiciliar no Brasil, bem como, de que forma pode o STF se valer do direito comparado para o estudo e a resolução do problema.

\section{HOMESCHOOLING: EDUCAÇÃO DOMICILIAR NO BRASIL E A POSSÍVEL UTILIZAÇÃO DO DIREITO COMPARADO PELO STF NO JULGAMENTO DO RECURSO EXTRAORDINÁRIO 888.815/RS}

Tramita no STF o Recurso Extraordinário $888815 / \mathrm{RS}^{32}$, em que se discute, conforme a descrição disponibilizada pelo Tribunal, à luz dos arts. 205, 206, 208, 210, 214 e 229, da Constituição Federal, a possibilidade de o ensino domiciliar (homeschooling) ser proibido pelo Estado ou viabilizado como meio lícito de cumprimento, pela família, do dever de prover educação. A relatoria é do Ministro Roberto Barroso. O Tribunal, por maioria, reconheceu a existência de repercussão geral da questão constitucional suscitada, vencidos os Ministros Dias Toffoli e Teori Zavascki. Manifestações pelos Ministros Marco Aurélio e Teori Zavascki. (BRASIL, 2015)

No caso, discutem-se os limites da liberdade dos pais na escolha dos meios pelos quais irão prover a educação dos filhos, segundo suas convicções pedagógicas, morais, filosóficas, políticas e/ou religiosas ${ }^{33}$.

31 Petição 65992/2016: Em razão da relevância dos argumentos apresentados e do reconhecimento da repercussão geral, determino a suspensão do processamento de todos os processos pendentes, individuais ou coletivos, que versem sobre a questão e tramitem no território nacional, nos termos do art. $1.035, \S 5^{\circ}$ do $\mathrm{CPC} / 2015$ e do art. 328 do RISTF. (STF. Recurso Extraordinário 888.815/RS. Inteiro teor disponível em: <http://www.stf.jus.br/portal/jurisprudenciaRepercussao/verAndamentoProcesso.asp?incidente $=47$ 74632 \&numeroProcesso $=888815 \&$ classeProcesso $=$ RE\&numeroTema=822> . Acesso em 19 mar. 2017).

32 Vide STF. Recurso Extraordinário 888.815/RS. Inteiro teor disponível em: <http://www.stf.jus.br/portal/jurisprudenciaRepercussao/verAndamentoProcesso.asp?incidente $=47$ 74632\&numeroProcesso=888815\&classeProcesso=RE\&numeroTema=822>. Acesso em: 19 mar. 2017.

33 Ran Hirschl (2009, p. 1.340 e ss.) apresenta o caso das irmãs Polgár, três jogadoras de xadrez de mundialmente famosas da Hungria. Elas são produto da educação domiciliar. Seu pai, um aficionado de xadrez educou as três meninas em casa, a fim de provar que as crianças poderiam 
A manifestação do relator ressalta que a Constituição Federal de 1988 prevê a educação como direito fundamental, cuja efetivação é dever conjunto do Estado e da família. Segundo o Ministro Barroso (BRASIL, 2015), no art. 208 da CF/1988, são previstos tão-somente os meios pelos quais será efetivada a obrigação do Estado com a educação. Assim, conforme se depreende do Acórdão, a controvérsia envolve a definição dos contornos da relação entre Estado e família na educação das crianças e adolescentes, bem como os limites da autonomia privada contra imposições estatais.

A família que recorre ao STF, para pleitear o direito de educar sua filha em casa, alega violação aos arts. 205, 206, 208, 210, 214 e 229 da Constituição, argumentando que:

[...] restringir o significado da palavra educar simplesmente à instrução formal numa instituição convencional de ensino é não apenas ignorar as variadas formas de ensino agora acrescidas de mais recursos com a tecnologia como afrontar um considerável número de garantias constitucionais, cujo embasamento se dá, entre outros, pelos princípios da liberdade de ensino (art. 206, II, CF) e do pluralismo de ideias e de concepções pedagógicas (art. 206, III, CF), tendo-se presente a autonomia familiar assegurada pela Constituição ${ }^{34}$.

A repercussão geral foi reconhecida tendo em vista que o interesse alcança várias famílias e, segundo o relator, tem relevância especialmente do ponto de vista social, jurídico e econômico.

Para o Ministro Barroso ${ }^{35}$, do ponto de vista social, a questão tem relevância em razão da própria natureza do direito pleiteado, tanto que previsto no art. $6^{\circ}$, caput, c/c art. 205, da Constituição, como direito de todos e meio essencial ao exercício da cidadania e à qualificação para o trabalho.

Afirma, também, que a relevância jurídica está relacionada à interpretação e alcance das normas constitucionais que preveem a liberdade de ensino e o

realizar feitos excepcionais se treinados por um especialista desde a mais tenra idade. "Gênios são feitos, não nascidos" era seu lema. A irmã mais velha, Susan, se tornou a melhor jogadora feminina no mundo com a idade de quinze anos. Ela foi a primeira mulher a ganhar o título de Grandmaster em competição regular, e foi campeã mundial de xadrez feminino de 1996 a 1999. A irmã Sofia atordoou o mundo do xadrez com a idade de quatorze anos, com seu brilhante desempenho em um torneio em Roma, em 1989. A irmã mais nova, Judit Polgár, é a jogadora de xadrez feminino mais forte da história.

34 STF. Recurso Extraordinário 888.815/RS. Inteiro teor disponível em: <http://www.stf.jus.br/portal/ jurisprudenciaRepercussao/verAndamentoProcesso.asp? incidente $=4774632$ \&numeroProcesso $=88$ 8815\&classeProcesso=RE\&numeroTema=822>. Acesso em: 19 mar. 2017.

35 STF. Recurso Extraordinário 888.815/RS. Inteiro teor disponível em: <http://www.stf.jus.br/portal/ jurisprudenciaRepercussao/verAndamentoProcesso. asp?incidente $=4774632 \&$ numeroProcesso $=88$ 8815\&classeProcesso=RE\&numeroTema=822>. Acesso em: 19 mar. 2017. 
pluralismo de ideias e concepções pedagógicas (art. 206, I e II, da CF/1988), bem como à definição dos limites da relação entre Estado e família na promoção do direito fundamental à educação. Por fim, afirma que a relevância tem também viés econômico, tendo em conta que, segundo os estudos citados no acórdão, o reconhecimento do homeschooling poderia reduzir os gastos públicos com a educação.

Apesar de reconhecida a repercussão geral, o STF tem ainda um árduo trabalho pela frente e, a fim de solucionar se a questão poderá se utilizar, para além da interpretação constitucional, também do Direito Comparado, tendo em vista que o homeschooling já foi expressamente legalizado em diversos países, como se demonstra no mapa:

\section{Figura 1: Educação domiciliar no mundo}

\section{Home Education Status Across the Globe}

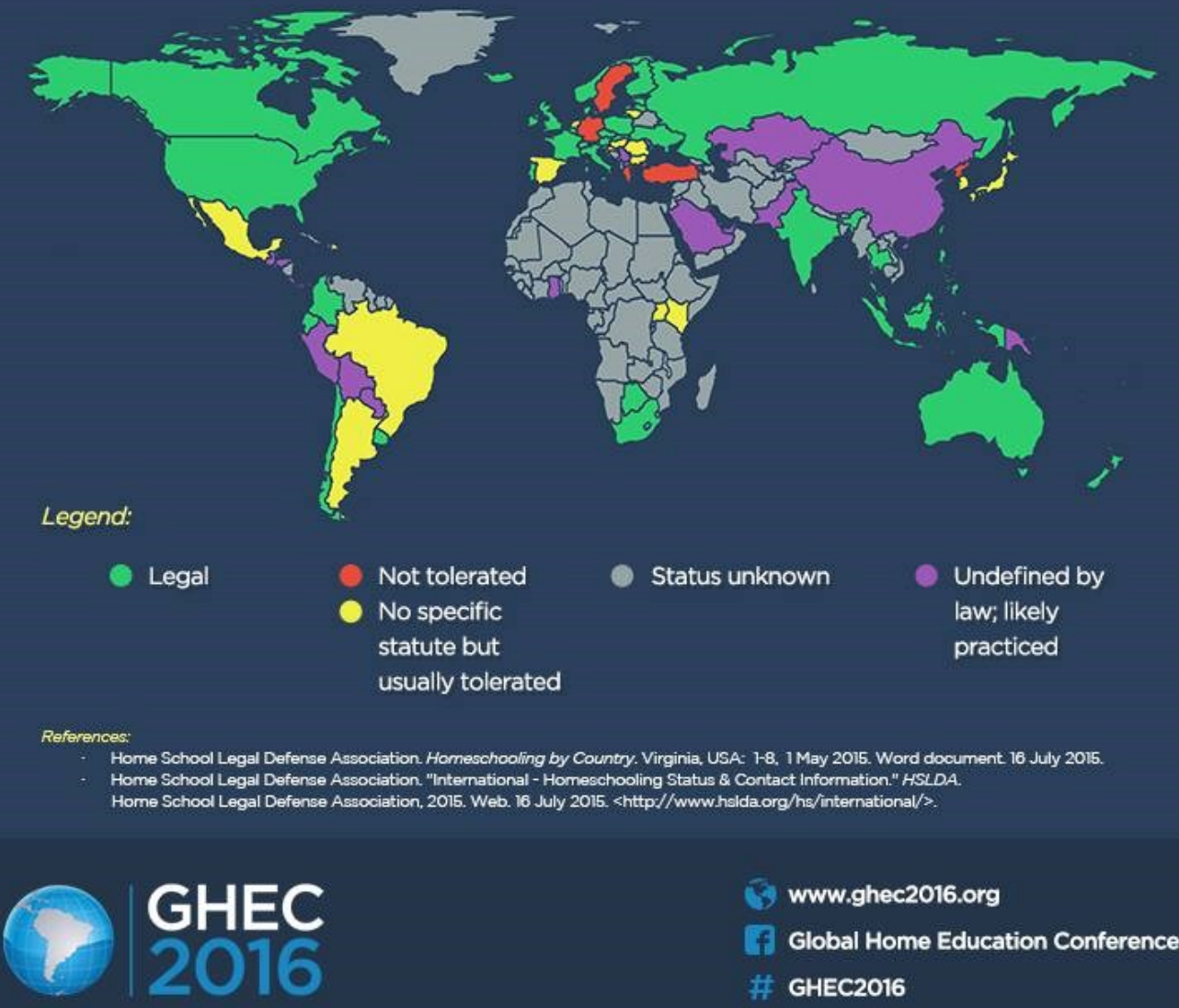

Fonte: <http://matter.mx/articulos/homeschooling-en-el-mundo/> 
Assim, conforme notado pelo próprio Ministro Relator do Recurso Extraordinário, a educação domiciliar é legalmente admitida em pelo menos 63 países no mundo. Esse é um dado da associação americana, HSLDA (do inglês Home School Legal Defense Association), que acompanha a educação em casa no mundo todo. (STF, 2015)

Segundo Martinez (2008, p. 395), graças ao processo denominado globalização, as práticas jurídicas também sofreram grandes transformações, sendo comum que os modelos legislativos de um país sejam transplantados para outros, bem como, as teorias jurídicas de países que adotam um tipo de pensamento sejam levadas a países que passam a receber tais ideias, transformando-as conforme as suas próprias necessidades e costumes. De tal forma que a utilização do direito comparado é uma realidade global, sendo imperiosa a adoção de metodologias adequadas.

Ou seja: há vasto material estrangeiro que poderá ser estudado pela Corte brasileira a fim de melhor decidir acerca da matéria. Entretanto, a utilização do direito comparado pelos Ministros do STF deverá se dar de forma científica e ordenada, sob pena de a solução adotada refletir a realidade do país comparado, e não a realidade brasileira. Deverá respeitar, também, os contornos constitucionais acerca da educação.

Sobre a questão do projeto ou do 'design' Constitucional e seu sucesso, Ran Hirschl (2009, p. 1.340 e ss.) afirma existir vasta literatura. Para o autor, uma boa Constituição traz resultados sociais e políticos desejáveis, conquistados por meio de um planejamento e implementação institucional adequados, bem como, frequentemente, é necessária a busca da melhor ou mais adequada regra constitucional, tendo em conta a cultura do país. No Brasil, cabe ao STF sugerir a "melhor prática" na situação do homeschooling, até que haja regulamentação do Parlamento, levando-se em conta a combinação ideal de regras e instituições dentro do regime democrático. Assim, a prática da educação domiciliar embora tenha respaldo constitucional, como já demonstrado, deve respeitar as peculiaridades da cultura brasileira, sem dar margem a legalização do abandono intelectual. Nesse ponto, é importante a observância de países em que o Estado, embora garanta a liberdade de educação, permita a avaliação e acompanhamento do menor. 
No que diz respeito a configurações conflitantes, o projeto constitucional é visto como um meio de atenuar tensões profundas nas questões étnicas, linguísticas, religiosas ou culturais. Neste contexto, o objetivo de médio prazo do projeto constitucional é reduzir o nível de violência, aumentar a credibilidade e a confiança entre as partes interessadas, lançando as bases do nexo entre as instituições políticas, ditando procedimentos que permitam a unidade, a paz e a estabilidade. As disposições constitucionais e as instituições devem ser otimizadas de modo a induzir, apoiar ou permitir que as mudanças necessárias beneficiem a Democracia. (HIRSCHL, 2009, p. 1.340). A utilização do direito comparado é valiosa, nesse sentido, para a discussão da constitucionalidade da educação domiciliar, devendo o STF se pautar em tal recurso para a resolução do problema e, finalmente, criar melhores oportunidades para servir o bem público no caso.

Conforme observado por Gustavo Vitorino Cardoso (2010, p. 5) em pesquisa sobre o uso da comparação de direitos pelo Supremo Tribunal Federal, tanto a doutrina como a jurisprudência de outros países são constantemente invocadas nos votos proferidos pelos ministros da Corte Suprema brasileira. Para Cardoso (2010, p. 5):

[...] principalmente os votos exarados pelos ministros Gilmar Ferreira Mendes, Celso de Mello, Joaquim Barbosa, Ellen Gracie e Eros Grau, que o fazem como forma de qualificação do debate e de aprofundamento das análises e argumentações desenvolvidas nos julgamentos, elidindo que o uso da comparação seja considerado mera citação decorativa. O resultado pode ser observado em decisões interessantemente fundamentadas e ricas culturalmente, alcançando, por conseguinte, a própria melhora da jurisprudência interna.

Entretanto, o STF às vezes peca pelo uso da citação decorativa em suas decisões, ou seja, quando se utiliza de um excerto de uma lei ou jurisprudência estrangeira de forma descontextualizada da situação cultural do país de origem, bem como, sem considerar a realidade do Brasil. Há críticas ao Tribunal quando, ao transcrever o direito estrangeiro para as decisões nacionais, não situa o leitor sobre o contexto em que aquela decisão foi exarada, de tal forma que a utilização do Direito Comparado pelo STF nem sempre é feita de forma a considerar as peculiaridades de cada sociedade. Nota-se que o STF não se vale de uma metodologia adequada na utilização do direito comparado, lançando mão, no mais 
das vezes, da técnica apenas para ilustrar e argumentar, sem, contudo, aprofundarse adequadamente na exegese ou na racio utilizada em cada caso.

Martinez (2008, p. 396) afirma que os juízes estão cada vez mais se utilizando de casos de jurisdições externas para solucionar os problemas de sua competência, quando encontram uma similitude nos direitos, similitude nas razões de análise dos casos concretos, adotando soluções semelhantes, inclusive no que se refere a casos em que haja vazio jurídico, com a utilização de norma estrangeira, ou na resolução de casos difíceis.

Segundo Ran Hirschl (2006, p. 126), existem cinco tipos de metodologia a fim de se fazer de forma correta a utilização do Direito Comparado na resolução da questão, de tal forma que é imperiosa a utilização da metodologia de comparação adequada, conforme cada caso concreto. Assim, na escolha dos casos ou textos legais para comparação do direito, entende o autor ser necessária a autorreflexão através da distinção, analogia e contraste, sendo que a pesquisa comparativa deve ser destinada a gerar conceitos densos e ferramentas de pensamento através de descrições multifacetada, com uma descrição múltipla.

Samuels (2014, p. 45 e ss.), por sua vez, afirma que o comparatista deve reconhecer as diferenças entre fatos ou objetos comparados a fim de criar um eixo de comparação consistente. Após, deve estabelecer e delimitar os critérios de comparação, bem como, colocar os fatos ou objetos a serem comparados em uma relação não hierárquica.

Assim, caso o STF se utilize do Direito comparado para a resolução da questão da constitucionalidade do ensino domiciliar, seja com utilização de estudo acerca de lei estrangeira ou pelo estudo de jurisprudência, deverá se atentar primeiramente à questão metodológica, escolhendo de forma coerente os casos, países e legislação estrangeira, atentando-se, também, para as diferenças culturais existentes entre os países que adotam como legal a prática do homeschooling. Isso porque, conforme entende Häberle (2003, p. 124), o Direito Constitucional diz respeito não só à interpretação técnica, mas também à interpretação cultural.

Nas palavras de Hirschl (2005, p. 129):

O estudo comparativo tem mais a oferecer do que a auto-reflexão ou o avanço orientado normativamente de valores cosmopolitas através de comparação. A comparação é uma ferramenta fundamental da análise acadêmica. Ela aguça nosso poder de descrição e desempenha um papel central na formação de conceitos, clarificando semelhanças e diferenças potenciais entre os casos. Esse fim é precisamente o raciocínio de um 
terceiro (e, possivelmente, mais sofisticado) tipo de investigação comparativa que se destina a gerar conceitos ricos e estruturas analíticas para pensar criticamente sobre normas e práticas constitucionais. Isto é feito principalmente através de uma busca por uma compreensão detalhada de como as pessoas que vivem em diferentes contextos culturais, sociais e políticos lidam com dilemas constitucionais que são assumidos como sendo comuns à maioria dos sistemas políticos modernos.

Na medida em que a questão em tela já foi enfrentada em outros países, é natural que o STF se utilize do direito comparado a fim de buscar as experiências consolidadas. Trata-se de caso difícil, sendo o estudo da constitucionalidade da prática da educação domiciliar imprescindível para o STF, bem como, do direito externo de outros países democráticos, até porque é mais comum o uso de decisões ou de Direito Constitucional comparado em matéria de Direitos Fundamentais, como o presente. Contudo, é necessária a contextualização social, econômica, cultural e política do problema da educação domiciliar no país comparado em relação ao Brasil.

Veja-se que no acórdão em que se reconheceu a repercussão geral no Recurso Extraordinário 888.815/RS ${ }^{36}$, o relator, Ministro Barroso, já se utilizou de dados estrangeiros, ao citar a associação americana, HSLDA (Home School Legal Defense Association) acerca do número americano de estudantes domiciliares: "nos Estados Unidos, para vocês terem uma ideia, o número de estudantes domiciliares cresceu $75 \%$ desde 1999 . Os estudantes domiciliares já compõem $4 \%$ da população em idade escolar nos Estados Unidos, país que tem a maior população de estudantes domiciliares".

É possível, portanto, como sinalizado no próprio acórdão, que o STF se utilize do Direito americano para a resolução do embate, tendo em vista que o país permite o homeschooling em todos os Estados, sendo a prática bastante comum. Conforme observam Cecilia Caballero Lois e Gabriel Lima Marques (2015, p. 33) os "tribunais, através de um processo de justificação discursiva, vêm se apropriando do material comparado assim como se faz com os conselhos de alguém mais experiente, para tomar decisões sobretudo em casos que envolvam questões de natureza complexa". No caso da educação domiciliar, a utilização do Direito Comparado será ainda mais valiosa, levando-se em consideração que o Supremo não enfrentou a matéria anteriormente.

36 STF. Recurso Extraordinário 888.815/RS. Inteiro teor disponível em: <http://www.stf.jus.br/ portal/jurisprudenciaRepercussao/verAndamentoProcesso.asp?incidente $=4774632$ \&numeroProce Sso=888815\&classeProcesso=RE\&numeroTema=822>. Acesso em: 19 mar. 2017. 
Os EUA, embora apresentem diferenças culturais, sociais e políticas bastante expressivas em relação ao Brasil, têm no currículo a liberação da prática da educação domiciliar em todos os 50 Estados. A Suprema Corte dos Estados Unidos nunca se pronunciou especificamente sobre educação domiciliar, mas em Wisconsin v. Yoder, $(1972)^{37}$, apoiou os direitos dos pais Amish para manter seus filhos fora das escolas públicas por razões religiosas. A Corte decidiu, no entanto, que os pais têm um direito fundamental de "estabelecer um lar e criar filhos", juntamente com o direito de "adorar a Deus de acordo com os ditames de sua própria consciência". Essa combinação de direitos é a base para considerar o homeschooling um direito fundamental sob o conceito da Suprema Corte Americana. Quanto à legislação, os Estados podem ser mais moderados ou mais conservadores em relação à prática, conforme se percebe na representação gráfica:

\section{Figura 2: Regulamentação do Homeschooling nos EUA}

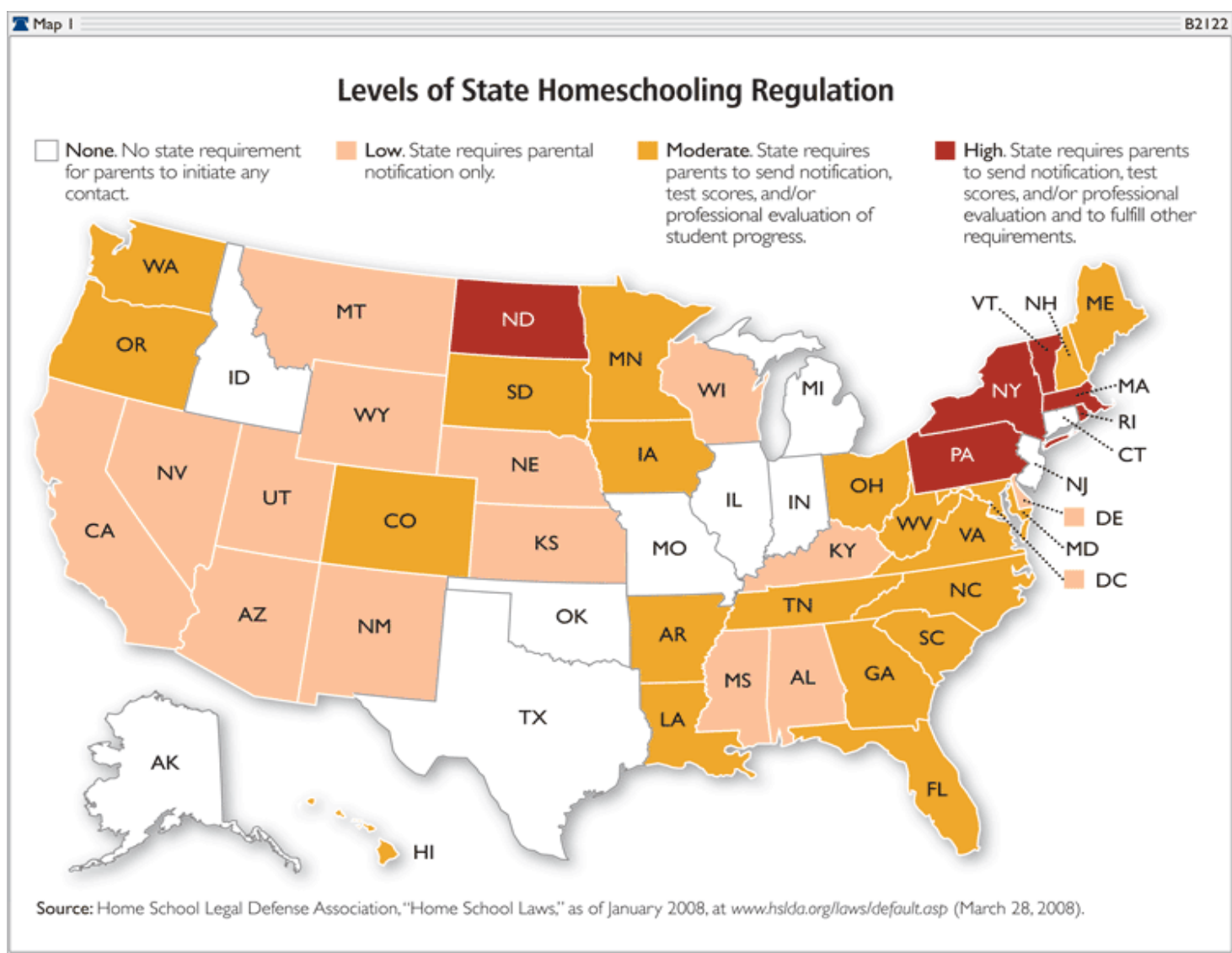

Fonte: <http://www.heritage.org/research/reports/2008/04/homeschooling-a-growing-optionin-american-education>.

37 Disponível em: < https://supreme.justia.com/cases/federal/us/406/205/case.html> Vide também: <https://web.archive.org/web/20060118165335/http://www.oyez.org/oyez/resource/case/449/>.

Acesso em: 22 jan. 2017. 
A Suprema Corte dos Estados Unidos reconheceu que os pais têm o direito fundamental de dirigir a criação educacional de seus filhos já no ano de 1925:

\begin{abstract}
A teoria fundamental da liberdade sobre a qual todos os governos desta União repousam, exclui qualquer poder geral do Estado para padronizar suas crianças, forçando-as a aceitar o ensinamento de apenas professores públicos. Uma criança não é a mera criatura do Estado; aqueles que a nutrem e dirigem o seu destino possuem o direito, juntamente com 0 elevado dever, de reconhecê-la e prepará-la para obrigações adicionais. (apud MOREIRA, 2016, p. 4)
\end{abstract}

Sobre a educação domiciliar e a intervenção do Estado, Ran Hirschl e Ayelet Shachar (2009, p. 2.553) ${ }^{38}$ discorrem acerca de um caso ocorrido no Canadá (6 R. v. Jones, [1986] 2 S.C.R. 284 (Can.). em que um pastor de uma Igreja fundamentalista de Alberta não teve permissão de educar seus três filhos no porão da Igreja. Nesse caso, a Alberta Schools Act exigia que os pais enviassem seus filhos para uma escola pública, ou escola particular credenciada, ou que o Governo deveria aprovar previamente o currículo que seria ministrado em homeschool. O pastor, de nome Jones, era acusado de absentismo escolar, pois estaria infringindo a "Lei das Escolas". Em resposta, ele desafiou a própria autoridade de direito geral sobre o assunto, argumentando que a regra de exigir a aprovação do governo para educar seus filhos envolveria afronta a sua fé, já que "se estaria reconhecendo que o governo, em vez de Deus, tem a Autoridade sobre a educação de seus filhos" e, portanto, estaria cerceado o seu Direito à liberdade de religião na acepção da alínea a) do artigo 2 da Carta Constitucional Canadense.

Em resposta, o Tribunal rejeitou o argumento religioso contra a intervenção estatal na educação, considerando que existia um interesse maior do Estado na proteção da educação, devendo os pais serem credenciados para exercer o homeschooling, mediante aprovação de currículo prévio. O Tribunal de Justiça, portanto, rejeitou a afirmação de Jones de que não estaria obrigado à certificação do Estado, não proibindo, contudo, a prática, desde que feita dentro da lei.

Hoje, o Canadá é um dos países em que a prática da educação domiciliar é amplamente difundida, havendo diversos precedentes interessantes a serem estudados $^{39}$. O país tem algumas das leis homeschooling mais favoráveis do mundo.

38 Tradução livre das autoras.

39 Citamos aqui algumas dos casos mais relevantes: 
Como a educação é da competência provincial, as leis variam de província para província. Cada província, exceto Ontario, exige que as famílias que estudam em casa informem o conselho escolar local de sua intenção de estudar em casa, a cada ano escolar. Algumas províncias exigem que planos de ensino sejam submetidos ao superintendente local de educação (Alberta, Saskatchewan, Manitoba e Prince Edward Island). Apenas uma província (Manitoba) exige a apresentação de dois relatórios anuais de progresso para cada criança escolarizada. Em cada província, as leis ou políticas indicam que, em circunstâncias em que há evidência de que uma família não estar fornecendo instrução satisfatória em casa, o Ministério da Educação tem o direito de proceder a uma investigação ${ }^{40}$.

Diante do exposto, é possível que o Supremo Tribunal Federal se utilize, também, do Direito Comparado canadense, tendo em vista o sucesso da prática, amparada por um controle estatal mais ativo e eficaz.

Além dos países de democracia avançada citados, é importante frisar que a prática da educação domiciliar também é aceita em países mais pobres, tal como a Índia. É comum pensar que apenas países ricos ou até mesmo que apenas famílias ricas praticam o homeschooling, sendo tal pensamento incorreto. A Índia possui similaridades sociais e econômicas com o Brasil, bem como, conta com uma

Brunelle Decision by the Supreme Judical Court: The plaintiffs sought a declaration that the school committee's policy to require home visits violates their rights under Massachusetts law, and injunctive relief enforcing the declaration. (Docket No.: SJC-07709. Parties: MICHAEL BRUNELLE \& others(1) vs. LYNN PUBLIC SCHOOLS.(2). County: Essex. Dates: November 5, 1998. December 16, 1998. Disponível em: < http://mhla.org/information/massdocuments/brunelle.htm>. Acesso em: 19 mar. 2017.

Calabretta v Floyd: This case involves whether a social worker and a police officer were entitled to qualified immunity, for a coerced entry into a home to investigate suspected child abuse, interrogation of a child, and strip search of a child, conducted without a search warrant and without a special exigency. The Calabrettas are a Christian homeschool family in California. (No. 9715385. Decided: August 26, 1999). Disponível em: < http://caselaw.findlaw.com/us-9thcircuit/1149036.html>. Acesso em: 19 mar. 2017.

Care and Protection of Charles: MHLA presents the turning point legislation that is the homeschooling law for Massachusetts. Disponível em: <http://mhla.org/information/massdocuments/charles.htm>. Acesso em: 19 mar. 2017.

Care and Protection of Ivan: In the present case, it was always open to the parents to work out an accommodation of their interests along the lines suggested by school authorities and to resolve the matter by agreement. However, the judge found that the parents never filed educational plans that were minimally adequate within the guidelines set forth in Charles. (No. 98-P-2166. APPEALS COURT OF MASSACHUSETTS 48 Mass. App. Ct. 87; 1999 Mass. App. LEXIS 1117. May 14, 1999, Argued October 14, 1999, Decided). Disponível em: <http://mhla.org/information/massdocuments/ivan.htm>. Acesso em: 19 mar. 2017.

40 Protecting Your Family: Homeschooling Law in Canada. Disponível em: <http://naturalparentsnetwork.com/homeschooling-law-canada/>. Acesso em: 19 mar. 2017. 
numerosa população, da ordem de 1,21 bilhões de pessoas, contra 206 milhões de habitantes, no Brasil. O IDH da Índia é de 0,554, ocupando a $136^{\circ}$ posição no ranking mundial ${ }^{41}$, sendo que o Brasil possui IDH de $0,755^{42}$ (101 a posição). Nota-se que o contexto econômico e social é similar. A Associação Indiana de Homeschoolers atua ativamente no país para apoiar, representar, proteger e capacitar homeschoolers (pais, tutores e estudantes), defender os direitos das crianças aprenderem num ambiente saudável e sem restrições, possibilitado por métodos tradicionais ou não tradicionais de aprendizagem, defender o direito de todas as crianças homeschoolers a fazer os exames apropriados para admissões em faculdades na Índia ou no exterior, assegurar que as crianças homeschoolers não sejam discriminadas de nenhuma maneira, bem como, faz o trabalho de aconselhamento dos pais que desejam conhecer ou optar por tal abordagem para a educação de seus filhos ${ }^{43}$. Recentemente, no ano de 2012 , houve uma discussão sobre a legalidade da prática da educação domiciliar, em resposta a petição de No 8870 de 2011. O deputado SH DP Majhi (Subsecretário do Departamento de Educação e Alfabetização no Ministério do Desenvolvimento dos Recursos Humanos do Governo da Índia), afirmou claramente que não há nada de ilegal sobre homeschooling, de tal forma que o governo reconheceu não haver qualquer irregularidade na prática, sendo a petição arquivada pela Delhi High Court" ${ }^{44}$.

No âmbito da América do Sul, apenas um país possui legislação permitindo expressamente a prática da educação domiciliar: o Equador ${ }^{45}$. Por outro lado, referida prática tem sido bem tolerada, embora não regulamentada por nenhuma lei específica, na Colômbia ${ }^{46}$, país que mais similitude apresenta em relação ao Brasil, especialmente nas questões econômicas e culturais. O IDH na Colômbia em

41 Dados disponíveis em: <http://www.deepask.com/goes?page=india-Confira-a-evolucao-do-IDH--indice-de-desenvolvimento-humano---no-seu-pais>. Acesso em: 19 mar. 2017.

42 Dados disponíveis em: <http://www.br.undp.org/content/brazil/pt/home/idh0.html>. Acesso em: 19 mar. 2017.

43 Informações disponíveis em: <http://homeschoolers.in/about-us/>. Acesso em: 19 mar. 2017.

44 Disponível em: <http://homeschoolers.in/government-of-india-states-that-there-is-nothing-illegalabout-homeschooling/>. Acesso em 19 mar. 2017.

45 No país, a prática é legal, mas não comum, como nos EUA ou Canadá. Há uma associação chamada HSLDA que atua desde 1983 para defender o direito das famílias homeschoolers. Informações disponíveis em: < https://www.hslda.org/default.aspx>. Acesso em: 19 mar. 2017.

46 "La situación legal de la educación en casa en Colombia no está definida, podría decirse que se encuentra en un "vacío legal". Disponível em: < http://www.enfamilia.co/consideraciones-legalesde-la-educacion-en-casa-en-colombia/>. Acesso em: 28 mar. 2017. 
educação o coloca na $103^{a}$ posição mundial, enquanto que o Brasil se encontra na $101^{a}$ posição.

É certo que a responsabilidade no STF é enorme: caso entenda pela constitucionalidade da prática da educação domiciliar, lançará ao legislativo a incumbência de regulamentar a questão, tendo em vista que a realidade brasileira exige um acompanhamento mais próximo dos Poderes, bem como, uma fiscalização efetiva das famílias que estejam educando em casa. A decisão do STF, nesse particular, caso entenda pela constitucionalidade do homeschooling, como aqui se defende, poderá inclusive lançar luz ao Legislativo, se se utilizar adequadamente de legislação estrangeira, a fim de que se desengavetem os projetos de lei e emenda constitucional sobre o tema.

Caso o STF pretenda se utilizar do direito comparado para embasar decisão de ilegalidade do homeschooling, terá um trabalho mais árduo, vez que a prática só é expressamente proibida na Suécia, Alemanha ${ }^{47}$, Grécia e Turquia, países que possuem enormes diferenças culturais, sociais e econômicas em relação ao Brasil.

\section{CONCLUSÃO}

Embora a legislação brasileira não seja expressa no que se refere à proibição ou permissão da prática do ensino domiciliar, vimos que tanto a Constituição Federal quanto a legislação infraconstitucional dão azo à interpretações diversas, tanto no sentido de que a escolarização é obrigatória, quanto no sentido de que apenas a educação é obrigatória, cabendo aos pais a escolha da melhor forma

$47 \mathrm{Na}$ Alemanha há inclusive refugiados, que receberam asilo nos EUA por ter sido cerceada a liberdade de educação de seus filhos em casa. Notícia disponível em: <http://www.dw.com/en/usjudge-grants-german-homeschooling-family-asylum/a-5174919>. Acesso em: 17 jan. 2017.

De fato, a escolarização obrigatória na Alemanha remonta ao regime totalitário nazista: "But attacks on individual liberty and freedom, especially in the context of education, are not a new development in Germany. They are, in fact, vestiges of Germany's totalitarian regime in the early 20th century. When Adolf Hitler rose to power in the early 1930s, the Nazis subordinated years of cultural progress in the arts and sciences to the predilections of the State." (MARTIN, 2010, p. 226)

Em março de 2009, a Câmara dos Deputados da Geórgia aprovou a Resolução 850 da Casa, instando o Governo Federal alemão a legalizar a educação em casa. A resolução foi uma ilustração de como os grupos de defesa em todo os Estados Unidos pressionaram a Alemanha para mudar suas leis draconianas em relação ao homeschooling, leis que foram promulgadas em 1938 durante o regime nazista. Mas, enquanto legisladores estão pedindo a Alemanha para mudar suas leis, ocorrem verdadeiras batalhas dentro dos Estados Unidos sobre as mesmas questões. (MARTIN, 2010). Available at SSRN: <https://ssrn.com/abstract=1479974>. Acesso em: 19 mar. 2017. 
de prover o direto à educação, dentre elas, matriculando os filhos em escola ou fornecendo-a no âmbito da residência.

Vimos também que é crescente o número de famílias brasileiras que vêm optando pela prática do homeschooling, em especial, pela péssima qualidade da educação que tem sido oferecida nas escolas brasileiras, pelo aumento da violência ${ }^{48}$ e por questões religiosas e morais.

Fizemos uma reflexão acerca da exegese dos dispositivos constitucionais e infraconstitucionais que tratam da educação, e concluímos que há evidente lacuna legislativa, deixando inúmeros adeptos da prática da educação domiciliar em um limbo jurídico, o que acabou por levar a questão até o STF.

Nos posicionamos, a partir da interpretação da legislação apresentada, no sentido de que o direito à educação familiar se trata de direito fundamental, levandose em conta especialmente a Declaração Universal dos Direitos Humanos segundo a qual os pais têm prioridade de direito na escolha do gênero de instrução que será ministrada a seus filhos.

Por fim, analisamos o Recurso Extraordinário 888.815/RS, concluindo que é imprescindível ao STF a utilização do Direito Comparado existente sobre a matéria, sugerindo que o Tribunal lance seu olhar de forma mais dedicada aos Estados Unidos da América, ao Canadá, à Índia, ao Equador e à Colômbia, países em que a prática é difundida, em maior ou menor grau, ou que apresentam similitudes sociais, econômicas e políticas com o Brasil.

48 BCC. Escola é violenta com aluno, diz Cristovam Buarque. Disponível em: <http://www.bbc.com/portuguese/noticias/2014/08/140819_salasocial_eleicoes_educacao_cristova m_rm>. Acesso em: 19 mar. 2017. Cristovam Buarque, Ministro da Ëducação entre 2003 e 2004, afirma em entrevista concedida a BBC: "A sociedade brasileira é uma sociedade muito violenta hoje, então as pessoas se sentem no direito de agir violentamente, às vezes, até não necessariamente com agressão física, mas com palavras. As escolas estão rodeadas de traficantes, a violência do meio influencia. O outro é o fato de que a escola não é uma instituição valorizada e, ao não ser valorizada, as crianças também entram na mesma onda da não valorização, se sentem no direito de quebrar os vidros, se sentem no direito de levar as coisas pra fora. Aqui mesmo na UnB (Universidade de Brasília), eu vi a enciclopédia britânica sendo rasgada, porque o aluno em vez de tirar o xérox da folha que ele precisava, arrancou a página e levou. Os próprios professores são tratados como seres sem importância, que ganham salários baixos. Além disso os jovens sabem que saindo com o curso ou sem, de tão ruim que são os cursos, ele sabe que não agrega muito na vida dele. Os alunos não veem retorno da escola."

Vide, também: BBC. Goiás aposta em 'militarização' de escolas para vencer violência. Disponível em: <http://www.bbc.com/portuguese/noticias/2014/08/140819_salasocial_eleicoes_educacao_ escola_militarizada_rm>. Acesso em: 19 mar. 2017. 
Por todo o exposto, chega-se à conclusão de que o Estado brasileiro não vem cumprindo o seu papel constitucionalmente previsto de fornecer educação de qualidade, bem como, que o sistema de educação atual não garante o pluralismo de ideias e de concepções pedagógicas e que, embora já existam diversos projetos de lei e até Proposta de Emenda à Constituição que pretendem a legalização expressa da prática do ensino domiciliar, o STF, diante da inércia do legislativo, deverá zelar pelo seu papel de guardião da lei a fim de que a decisão não contrarie a liberdade individual e a supremacia dos Direitos Humanos.

\section{REFERÊNCIAS}

AGUIAR, Alexandre Magno Fernandes Moreira. A situação jurídica do ensino domiciliar no Brasil. Revista Jus Navigandi, Teresina, ano 16, n. 2929, 9 jul. 2011. Disponível em: <https://jus.com.br/artigos/19514>. Acesso em: 05 fev. 2017.

AGUILAR CAVALLO, Gonzalo. El control de convencionalidad: análisis en derecho comparado. Rev. direito GV, São Paulo, v. 9,n. 2, p. 721-754,Dec. 2013. Disponível em: $\quad$ <http://www.scielo.br/scielo.php?script=sci_arttext\&pid=S180824322013000200015\&lng=en\&nrm=iso>. Acesso em: dez. 2016.

ALEXY, Robert. Teoria dos Direitos Fundamentais. Tradução de: Virgílio Afonso da Silva. 2. ed., 3. tir. São Paulo: Malheiros, 2014.

ANED. Associação Nacional de Educação Domiciliar. [s.d.]. Belo Horizonte. Disponível em <http://www.aned.org.br/portal/index.php/ensino-domiciliar>. Acesso em: dez. 2016.

BARBOSA, L. M. R. Ensino em Casa no Brasil: Análise histórica de seus aspectos legais. Tese de Doutorado. Faculdade de Educação de São Paulo. São Paulo: USP, 2009.

BARBOSA, Luciane Muniz R. Ensino em casa no Brasil: um desafio à escola? 2013. 348 f. Tese (Doutorado) - Faculdade de Educação, Universidade de São Paulo, São Paulo, 2013. Disponível em: <http://www.teses.usp.br/teses/disponiveis/48/48134/tde-07082013-134418/ptbr.php>. Acesso em: 13 jan. 2017.

BARBOZA, Estefânia Maria de Queiroz. Jurisdição Constitucional: entre constitucionalismo e democracia. Belo Horizonte: Fórum, 2007. 
BARBOZA, Estefânia Maria de Queiroz. Precedentes judiciais e segurança jurídica: fundamentos e possibilidades para a jurisdição constitucional brasileira. São Paulo: Saraiva, 2014.

BARBOZA, Estefânia Maria de Queiroz; KOZICKI, Katya. Judicialização da política e controle judicial de políticas públicas. Rev. direito GV, vol. 8, n.1, São Paulo, jan./june 2012. DOI: <http://dx.doi.org/10.1590/S1808-24322012000100003>.

BCC. Escola é violenta com aluno, diz Cristovam Buarque. Disponível em: <http://www.bbc.com/portuguese/noticias/2014/08/140819_salasocial_eleicoes_educ acao_cristovam_rm>.

BBC. Goiás aposta em 'militarização' de escolas para vencer violência. Disponível em:

<http://www.bbc.com/portuguese/noticias/2014/08/140819_salasocial_eleicoes_educ acao_escola_militarizada_rm>. Acesso em: 19 mar. 2017.

BOUNDENS, E. Ensino em casa no Brasil. In: BRASIL. Consultoria legislativa da câmara dos deputados. Brasília. 2002.

BRASIL. Código Penal (1940). Disponível em: <http://www.planalto.gov.br/ccivil_03/decreto-lei/Del2848compilado.htm>. Acesso em: dez. 2016.

BRASIL. Constituição da República Federativa do Brasil (1988). Disponível em: <http://www.planalto.gov.br/ccivil_03/constituicao/constituicao.htm>. Acesso em: dez. 2016.

BRASIL. IBGE - Instituto brasileiro de geografia e estatística. Taxa de escolarização. Disponível em: <http://brasilemsintese.ibge.gov.br/educacao/taxade-escolarizacao-das-pessoas-de-6-a-14-anos.html>. Acesso em: 29 dez. 2016.

BRASIL. Lei n. 4.024 - Diretrizes e Bases da Educação Nacional. Disponível em: <http://www.planalto.gov.br/CCIVIL_03/leis/L4024.htm>. Acesso em: dez. 2016.

BRASIL. Lei n. 8.069 - Estatuto da Criança e do Adolescente. Disponível em: <http://www.planalto.gov.br/ccivil_03/LEIS/L8069.htm>. Acesso em: dez. 2016.

BRASIL. MEC - Ministério da Educação. Disponível em: <http://portal.mec.gov.br/component/content/article?id=39021>. Acesso em: 04 jan. 2017.

BRASIL. Projeto de Emenda à Constituição n 444 de 2009. Disponível em: <http://www.camara.gov.br/proposicoesWeb/prop_mostrarintegra?codteor=723417\&f ilename=Tramitacao-PEC+444/2009>. Acesso em 17 jan. 2017. 


BRASIL. Projeto de Lei 3179/2012. Disponível em:

$<$ http://www.camara.gov.br/proposicoesWeb/fichadetramitacao?idProposicao=53432 8>. Acesso em: 12 jan. 2017.

BRASIL. SUPREMO TRIBUNAL FEDERAL. Recurso Extraordinário 888815/2015. Disponivel em: <http://www.stf.jus.br/portal/jurisprudenciaRepercussao/ver AndamentoProcesso .asp incidente $=4774632 \&$ numeroProcesso $=888815 \&$ classePro cesso $=$ RE\&numeroTema $=822>$.

CARDOSO, Gustavo Vitorino. O direito comparado na jurisdição constitucional. Rev. direito GV, vol. 6 n. 2, São Paulo, dez./2010. DOI: <http://dx.doi.org/10.1590/S180824322010000200006>. Acesso em: 20 dez. 2016. CAVALLO, Gonzalo Aguilar. El control de convencionalidad: análisis em derecho comparado. Rev. direito GV vol.9 no.2 São Paulo jul./dic. 2013. DOI http://dx.doi.org/10.1590/S180824322013000200015.

DUMAS, Tanya K. and Gates, Sean and Schwarzer, Deborah, Evidence for Homeschooling: Constitutional Analysis in Light of Social Science Research (December 17, 2008). Widener Law Review, Forthcoming. Available at SSRN: <https://ssrn.com/abstract=1317439>. Acesso em: 19 mar. 2017.

DW GERMANY. US judge grants German homeschooling family asylum. Disponível em: <http://www.dw.com/en/us-judge-grants-german-homeschoolingfamily-asylum/a-5174919>. Acesso em: 17 jan. 2017.

Educação Domiciliar Reformada. Disponível em: <http://www.educacaodomiciliar.com/category/artigos/questoes-legais/>. Acesso em: 12 jan. 2017.

ESCOBAR-MARTÍNEZ, Lina Marcela. El uso del precedente extranjero por parte de la Corte Constitucional Colombiana. Int. Law: Rev. Colomb. Derecho Int. ildi. Bogotá (Colombia) N 13: 391-409, noviembre de 2008.

FERNANDEZ, Atahualpa; FERNANDEZ, Manuella Maria; FERNANDEZ, Atahualpa; FERNANDEZ, Manuella Maria. O "Caso Nunes": Homeschooling, Liberdade e "llícito Legal". Universo Jurídico, Juiz de Fora, ano XI, 01 out. 2009. Disponível em: $<$ <ttp://uj.novaprolink.com.br/doutrina/6508/O_Caso_Nunes_Homeschooling_Liberda de_e_llicito_Legal >. Acesso em: 06 fev. 2017.

FOLHA DE SÃO PAULO. $\mathbf{9 1 \%}$ das escolas públicas ficaram abaixo da média no Enem 2015. Disponível em: <http://www1.folha.uol.com.br/educacao/2016/10/ 
1819634-91-das-escolas-publicas-ficaram-abaixo-da-media-no-enem-2015.shtml>. Acesso em: 05 jan. 2017.

GLOBO. 'Ranking' do Enem por escolas deixará de existir; entenda a mudança. Disponível em: <http://g1.globo.com/educacao/enem/2017/noticia/ranking-do-enempor-escolas-deixara-de-ser-divulgado-diz-mec.ghtml>. Acesso em: 19 mar. 2017.

GLOBO. Série "Lições da Escola". Reportagem disponível em: <Https://www.youtube.com/watch?v=cSA239Vnrgq>. Acesso em: 19 mar. 2017.

G1. Pesquisador conclui que mais de $\mathbf{5 0 \%}$ dos universitários são analfabetos funcionais. Disponível em: <http://g1.globo.com/distritofederal/videos/v/pesquisador-conclui-que-mais-de-50-dos-universitarios-saoanalfabetos-funcionais/2262537/>. Acesso em: 05 jan. 2017.

HÄBERLE, Peter. El Estado constitucional. Tradução de Hector FixFierro. México: Universidad Nacional Autônoma de México, 2003.

HIRSCHL, Ran. The Question of Case Selection in Comparative Constitutional Law. American Journal of Comparative Law, Vol. 53, No. 1, pp. 125-155, Winter 2005; U Toronto, Legal Studies Research Paper No. 901700. Available at SSRN: <http://ssrn.com/abstract=901700>.

HIRSCHL, Ran. The "Design Sciences" and Constitutional "Success". Texas Law Review. [Vol. 87:1339]. 2009.

HIRSCHL, Ran. Comparative Matters. The Renaissance of Comparative Constitutional Law. Oxford: Oxford University Press, 2014.

HIRSCHL, Ran; SHACHAR, Ayelet. The New Wall of Separation: Permitting Diversity, restricting competition. Cardozo Law Review [Vol. 30:6]. 2009.

INSTITUTO PAULO MONTENEGRO. Indicador de analfabetismo funcional. Disponível em: <http://www.ipm.org.br/pt-br/programas/inaf/Paginas/default.aspx>. Acesso em: 05 jan. 2017.

LOIS, Cecilia Caballero Lois, MARQUES, Gabriel Lima. O Supremo Tribunal Federal e o Argumento de Direito Constitucional Comparado: Uma Leitura Empírica a partir dos Casos de Liberdade de Expressão no Brasil. Direito, Estado e Sociedade, n. 47 p. 32 a 63 jul./dez. 2015.

MARTIN, Aaron T., Homeschooling in Germany and the United States (May 28, 2010). Arizona Journal of International \& Comparative Law, Vol. 27, No. 1, p. 
225, 2010. Available at SSRN: <https://ssrn.com/abstract=1479974>. Acesso em: 19 mar. 2017.

MARTINEZ, Lina. El uso del precedente extranjero por parte de la corte constitucional colombiana. Int. Law: Rev. Colomb. Derecho Int. ildi. Bogotá (Colombia) N 13: 391-409, noviembre de 2008.

MIRANDA, Jorge. Manual de Direito Constitucional. Coimbra: Coimbra Editora, 1990.

MOREIRA, Alexandre Magno Fernandes. O direito à educação domiciliar. \{s.e.\} 2016. Disponível em: <https://www.researchgate.net/publication/303551238>. Acesso em: nov. 2016.

Programme for International Student Assessment (PISA). Disponível em: <http://www.oecd.org/pisa/>. Acesso em: 12 jan. 2017.

Protecting Your Family: Homeschooling Law in Canada. Disponível em: <http://naturalparentsnetwork.com/homeschooling-law-canada/>. Acesso em: 19 mar. 2017.

REVISTA EDUCAÇÃO. Apenas $16 \%$ dos profissionais da educação tem alto nível de alfabetização, diz estudo. Disponível em: <http://www.revistaeducacao.com.br/apenas-16-dos-profissionais-da-educacaopode-ser-considerado-completamente-alfabetizado-diz-estudo>. Acesso em: 05 jan. 2017.

SAMUELS, Geoffrey. An introduction to comparative law: theory and method. Hart Publishing, 2014.

SARLET, Ingo Wolfgang. A Eficácia dos Direitos Fundamentais. 11. ed. Porto Alegre: Livraria do Advogado, 2012.

STF. Recurso Extraordinário 888.815/RS. Inteiro teor disponível em: <http://www.stf.jus.br/portal/jurisprudenciaRepercussao/verAndamentoProcesso.asp ?incidente $=4774632 \&$ numeroProcesso $=888815 \&$ classeProcesso $=$ RE $\&$ numeroTema =822>. Acesso em: 19 mar. 2017.

STJ. MANDADO DE SEGURANÇA No 7.407 - DF (2001/0022843-7). Disponível em: $<$ http://www.mp.go.gov.br/portalweb/hp/42/docs/ms-ensino_fundamental7407_stj.pdf>. Acesso em: 19 mar. 2017.

TJ/MG. Apelação Cível 1.0687.07.054286-9/001. 0542869-16.2007.8.13.0687 (1). Rel. Des. Almeida Melo. Comarca de Origem: Timóteo. Data de Julgamento: 
04/12/2008. Data da publicação da súmula: 22/01/2009. Divulgação: Revista Jurisprudência Mineira, $\quad$ v. 187/183. Disponível em: <http://www4.tjmg.jus.br/juridico/sf/proc_resultado2.jsp?listaProcessos $=1068707054$ 2869001>.

THE ECONOMIST INTELLIGENCE UNIT LIMITED. Disponível em: $<$ http://country.eiu.com/brazil>. Acesso em: 12 jan. 2017.

TUSHNET, Mark. Comparative Constitutional Law. Massachusetts: Edward Elga Publishing, 2014.

UNDP. United Nations Development Programme. Disponível em: <http://www.undp.org >. Acesso em: 17 jan. 2017.

UOL EDUCAÇÃO. No Brasil, apenas $8 \%$ têm plenas condições de compreender e se expressar. Disponível em: <https://educacao.uol.com.br/ noticias/2016/02/29/no-brasil-apenas-8-escapam-do-analfabetismo-funcional.htm>. Acesso em: 10 jan. 2017. 